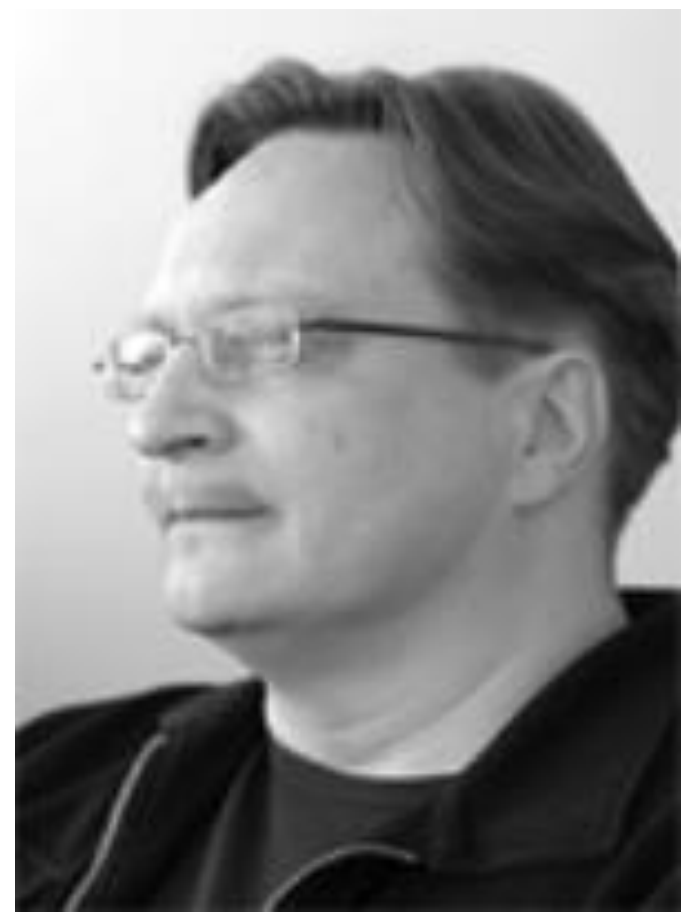

\title{
Jari-Erik Nurmi (1956-2017)
}

Jari-Erik Nurmi (1956-2017). Professor and Chair of the Department of Psychology, University of Jyväskylä. Born in a small village in Western Finland and reared in a union household, Jari was not one to let being a professor go to his head. His tastes were simple, his speech was plain, and his capacity for work was endless. Jari left his home in Harjunpää to attend the University of Turku, where he received his M.A. degree in 1980 and his licentiate degree in 1984. Along the way he grew his hair, learned to play the guitar, and got married (not necessarily in that order). As a newly minted psychologist, Jari worked in a remote psychiatric ward in Turku in lieu of mandatory military service, which both illustrated his principles and provided a great many interesting stories. Reluctantly, Jari cut his hair, opting for the mustache that accompanied him through much of his career. After a stint in the United States (and an M.A. degree from the University of Oregon), Jari moved to the University of Helsinki, where he earned his Ph.D. in Psychology in 1990. He remained for several more years, courtesy of a prestigious early career research appointment from the Academy of Finland. Jari was now the father of three children, who evinced varying degrees of enthusiasm for the next move, to Jyväskylä.

Jari flourished at the University of Jyväskylä. In between two stints as Department Chair, he was the Director of the Finnish Academy Center of Excellence in Learning and Motivation Research. Awards accumulated, including an honorary doctorate (Örebro University, Sweden), appointment to the Finnish Academy of Sciences, and a designation (by the President of Finland) as a First Class Knight of the White Rose. Life continued, as it does. His children grew, left home, graduated from university, and started impressive careers. Jari became a grandfather. He fished, took singing lessons, read detective novels, and tended his tomatoes (with mixed success). In the end, he asked to be returned to Harjunpää. 
Jari was a prodigious scientist. A quick search of Google Scholar reveals hundreds of papers, more than 50 with at least 100 citations. Outside of Finland, Jari was best known for his work on adolescence, particularly his scholarship on identity formation, personal goals, and future orientation. A new millennium brought new interests and Jari shifted his attention to school achievement, increasingly among preadolescent children. Within Finland (and beyond), he soon emerged as a leading expert on the role of motivation in learning and was increasingly sought after as a methodologist. Jari's work mattered to policy-makers, none more than his research on teacher-student relationships. Children in Finland continue to benefit from changes to schools that were the direct result of his research. Given Finland's position as a leader in education policy, it is safe to say that Jari's research will impact children the world over for years to come. He did not arrive at this level of prominence on his own. Jari supervised dozens of Ph.D. students, who serve with distinction at universities around Finland and abroad.

Jari was an indefatigable champion of developmental psychology in Finland and a well-travelled, well-recognized ambassador beyond the borders. He was elected to the Executive Committee of many professional societies, including the International Society for the Study of Behavioral Development (ISSBD), where he later served as Secretary General. He organized training workshops for junior scholars on behalf of ISSBD, in Finland and in Estonia. These were the stuff of legend. Don't take my word for it; many past and current leaders of the society were in attendance. There they learned to row boats, properly sauna, roast bread dough over a fire on a stick, eat and drink the unfamiliar, tango, and sing. Along the way there was interesting science.
Jari was a man of wry wit. He was good at having a good time. He had a beautiful voice, a magnificent laugh, and a mischievous smile. He listened, really listened, when you talked. It was not his practice to judge others. When he offered counsel, it was wise. Jari was proud to be a Professor. He was good at it. The job gave him purpose. Jari's door was always open to those who were thinking about something interesting and to those who wanted to talk about interesting thoughts. Jari was a unique individual, an unconventional force, a distinctive personality. We who enjoyed his presence are diminished by his absence.

Brett Laursen

Florida Atlantic University 